\title{
CONSERVATION OF HISTORICAL RESIDENTIAL BUILDINGS 1N URBAN SETTINGS
}

\author{
Janakie Edirisinghe ${ }^{1} \&$ Malik Ranasinghe ${ }^{2}$ \\ 1 Department of Estate Mgt. and Valuation, \\ University of Sri Jayewardenepura \\ ${ }^{2}$ Faculty of Engineering, University of Moratuwa
}

Historical areas and built heritage are important elements which contribute to create image and identity of a city. Its creativity and diversity are evidence of human progress and essential factor in development. Residential properties constitute a considerable portion of the built heritage and it is the major land use in a city's functional structure.

The characteristics such as architectural features, internal design, materials used for construction of houses enrich our knowiedge and understanding of the way we used to live. Those historical structures give pleasure to people, form a valuable economic, social and educational resource. They are also legacies of our past.

Many residential properties of important historical value in urban settings are confronted with a situation where they are either neglected or destroyed due to various reasons. The values inherent in such properties are rarely recognized and appreciated. The issucs and difficulties in conservation and management of old residential buildings in the context of urban development are analyzed and discussed in this paper. 